\title{
How Should A System Of Registered Title To Property Respond To Fraud And Sharp Practice?
}

\author{
GRAHAM FERRIS*
}

\section{INTRODUCTION}

We need a better account of registration of title to land in England and Wales. The register plays a central role in a broader system of property law that includes background law of property, institutional elements such as conveyancing professionals, lenders and the Financial Conduct Authority, and insolvency law. The narrative generally accepted is that unregistered conveyancing was nee dlessly complex and expensive and led to uncertainty in title, and registration was a technoc ratic reform that simplified, reduced costs, and ensure dcertainty in title or- if that was not possible- then compensation for failure of registered title.

The ideal was commercial land markets that approached the transaction costs of Government stock, as described by Anderson: 'Comparison of land transfer with the transfer of public stock consols - began in the 1840s and became a staple. ${ }^{1}$ This rhetorical emphasison low transaction costs, and speed of transaction, and security in reliance upon the register, was continued in the Law Commission Report that led to the Land Registration Act 2002. ${ }^{2}$

Obviously this emphasis on the marketability of land, land as exchange value, creates a tension with conceptions of land as specific property, valued for its use and expressive value. ${ }^{3}$ Registration deals with this tension by the linking of simple tradeable ownership interests with complex beneficial interests via the trust as the mediating institution. This enables much complexity to be dealt with outside of the market, treating the specific property as a fund of value to be distributed behind trusts. ${ }^{4}$ Interests behind trusts can be detached from the land, and realised as money. ${ }^{5}$ Law thereby enhances marketability and favours dynamic security at the price of putting at risk static security interests. ${ }^{6}$

Therefore, registration must deal with the opportunities for sharp practice and fraud in the land market it creates, and a narrative limited to reduced transaction costs is inadequate in this context. Furthermore, at a systemic level, failure to set out a clear position of principle on the issue is

\footnotetext{
* Nottingham Trent University

1 Stuart Anderson, 'Property', 190 in William Cornish, Stuart Anderson, Raymond Cocks, Michael Lobban, Patrick Polden, and Keith Smith, Oxford History of the Laws of England volume XII 1820-1914: Private Law (Oxford, Oxford University Press, 2010).

2 Law Commission, Land Registration for the Twenty-First Century (Law Com No 271, 2001) para 1.5. See WR Cornish \& G de N Clark, Law and Society in England 1750-1950 (London, Sweet \& Maxwell, 1989), 176.

3 Historically class conflict, between aristocratic and middle class ideas about property provided a frame for the politics of reform: Anderson in Cornish et al (2010), 193; Cornish \& Clark (1989), 166-172; see Thomas Edward Scrutton, Land in Fetters, or, the history and policy of the laws restraining the alienation and settlement of land in England (Cambridge, Cambridge University Press, 1886). Currently the tension is more between home owners and mortgagees - Lorna Fox, 'The Meaning of Home: A Chimerical Concept or a Legal Challenge?' (2002) Journal of Law \& Society 580; Lorna Fox O'Mahony, Conceptualising Home: Theory, Laws and Policies (Oxford, Hart Publishing, 2007).

${ }^{4}$ Bernard Rudden, The New River (Oxford, Oxford University Press, 1985) 214; Bernard Rudden, 'Things as Thing and Things as Wealth' (1994) 14 OJLS 81.

${ }^{5}$ City of London Building Society v Flegg [1988] AC 54 (HL).

${ }^{6}$ Elizabeth Cooke and Pamela O'Connor, 'Purchaser liability to third parties in the English land registration system: a comparative perspective' (2004) 120 LQR 640.
} 
inadequate. Thus, we need a registered land analogue of the bona fide purchaser doctrine, because that doctrine managed to combine a principled narrative with prophylactic systemic effects.

The argument will begin with a short account of how the bona fide purchaser doctrine operated. Then two types of systemic issues will be addressed, one establishing the complementary nature of fraud and sharp practice to market systems, and the second seeking to identify system design features that counteract this predictable mischief. Only after this will the evidence for problems in the operation of the current narrative be reviewed, specifically that the lack of a principled account puts pressure on the judiciary to undermine the articulated aims of the registration system. Finally, and very briefly, proposals for reform will be introduced.

\section{WHY IS THE INEFFICIENT BONA FIDE DOCTRINE IN UNREGISTERED CONVEYANCING IN CERTAIN RESPECTS SUPERIOR TO THE MORE EFFICIENT REGISTERED SYSTEM OF LAND TRANSFER AND OWNERSHIP?}

Efficiency in land transfer was always a central aim of registration, and lies behind the desire for electronic conveyancing. Efficiency here does not mean the optimal distribution of resources, but the lowest possible transaction costs. ${ }^{7}$ Transaction costs include time and fees expended on finding a suitable property; registration fees; legal fees; fees for surveys; and time spent visiting the property to view it and make inquiries of occupiers. Obviously not all of these costs can be reduced by title registration, nor be quantified. Some costs, such as those imposed in finding a property or buyer, are independent of title investigation. However, land registration is almostcertainly more efficient, in the sense of imposing lower total costs than the older system of unregistered conveyancing, which involved the investigation of title deeds and included the bona fide purchaser doctrine. ${ }^{8}$

Land registration has some element of state guarantee of titl e which provides certainty, and the law limits the potential impact of notice or its registered analogue, ${ }^{9}$ thus simplifying and cheapening the process of title investigation. Official searches provide quick and very reliable information, with compensation for Registry error. Of course overriding interests impair the reliability of the Register, and inaccurate entries which fail to warn of overriding interests do not generally result in the payment of compensation. ${ }^{10}$ However, for purchasers, whether seeking to obtain an estate in the land for occupation or other use or as security over land, the Register offers a relatively cheap and secure means to ascertain whether the vendor or mortgagor owns the land. Finally, as noted above registration is part of a larger system; most importantly, for dynamic security all purchasers can rely upon the operation of overreaching, and mortgagees can rely upon the special priority accorded to acquisition mortgages. ${ }^{11}$

Thus, it will be assumed that registration is, at least whilst Land Registry fees are at relatively low levels, more efficient in transaction cost terms than unregistered conveyancing. Thus, it seems

\footnotetext{
7 Efficiency as optimal distribution of resources is the eval uative criterion of much law and economics scholarship: Richard Posner, 'The Economic Approach to Law' (1975) 53 Texas Law Review 757.

8 Thomas J Miceli, Henry J Munneke, CF Sirmans, and Geoffrey K Turnbull, 'Title Systems and Land Values' (2002) 45 Journal of Law and Economics 565.

${ }^{9}$ The registered analogue to notice is occupation, as explained by William \& Glyn's Bank v Boland [1981] AC $487(\mathrm{HL})$, and entries on the Register; there is an analogue of the purchaser for value element of the bona fide purchaser in the Land Registration Act 2002, ss 29 and 30.

${ }^{10}$ Re Chowood's Registered Land [1933] 1 Ch 574 (Ch).

${ }^{11}$ City of London Building Society v Flegg [1988] AC 54 (HL); Abbey National Building Society v Cann [1991] 1 AC $56(\mathrm{HL})$.
} 
perverse to argue any aspect of unregistered conveyancing was superior. However, efficiency is not the sole relevant criterion for evaluation of property law. Two further criteria must be considered. First, whether the law offers a satisfying account of the justice of the system: does it offer a principled narrative of justification for its results? Second, does the law discourage fraud and sharp practice? This is not to dispute the value of efficiency, but to argue for the necessity of a richer evaluative frame.

The doctrine of the bona fide purchaser has at its foundation an ethical approach to the land market. Unregistered conveyancing protected legal interests through a strong principle of nemo dat quod non habet, which was robust against such frauds as forgery or identity theft. However, nemo dat could be a blunt instrument that left good faith purchasers vulnerable to undiscoverable fraud or error. The bona fide purchaser doctrine was inherently concerned with a fair balance between equitable owner and purchaser:

Such a purchaser, when he has once put in that plea, may be interrogated and tested to any extent as to the valuable consideration which he has given in order to shew the bona fides or mala fides of his purchase, and also the presence or the absence of notice; but when once he has gone through that ordeal, and has satisfied the terms of the plea of purchase for valuable consideration without notice ... [i]n such a case a purchaser is entitled to hold that which, without breach of duty, he has had conveyed to him. ${ }^{12}$

The ethical case is clear: equitable ownership will be protected as property rights are worthy of protection, however, if a purchaser has in good faith done all that it is reasonable to expect then it takes free of the equitable right. An innocent property holder should not be deprived of its property, but neither should a good faith market participant be forced to risk the loss of the purchase money. The purchaser's ethical claim is based on a good faith, purchase forvalue, and care in seeking out any hidden interest.

For our purposes it is not necessary to distinguish the prudential 'duty of care' placed upon a purchaser and the good faith of the purchaser. Traditionally, the 'duty of care' was found in the doctrine of constructive notice, and the requirement of good faith was divided between the express requirement of good faith, and aspects of imputed and constructive notice. Hence, instructing an agent not to report back on the existence of a defeasible equitable interest would be bad faith, and was made impossible by the doctrine of imputed notice. Similarly, constructive notice was capable of extending the necessary inquiries when circumstances raised suspicions - a Nelsonian denial was not safe, and this also has the effect of requiring good faith from the inquirer. Of course registration of title totally disrupted the details by which this division of labour and sharing of function between the concepts was made concrete in the law. For our purposes it is argued that the presence of circumstances that suggest fraud or sharp practice may either be taken to engage the requirement of good faith, or to extend the prudential duty of care.

Under this doctrine static security is protected, even without active efforts to bring it to the notice of potential purchasers. However, in support of dynamic security, if a purchaser for value investigates title in an appropriate and rigorous fashion, and does not uncover the interest, then it takes free of the interest. Thus, it was always about the balancing of two legitimate interests. The distinction between legal and equitable interests was an arbitrary aspect of the doctrine; however, subject to this aspect, the courts tried to decide on the basis of principles of justice.

The same approach also generates a prophylactic incentive for equitable owners and purchasers. Equitable owners can protect their interests through acts that publicise their interest.

12 Pilcher v Rawlins (1872) 7 Ch App 259 (CA), 268-269. 
Purchasers are driven by prudential self-interest to investigate title thoroughly and actively seek to discover any undisclosedinterests - as failure to be assiduous risks taking subject to the undiscovered interest. The doctrine harnesses self-interest to the system aim of honest dealing; it gives all the relevant parties an incentive to take steps to avoid fraud and sharp practice. ${ }^{13}$

The monitoring role is assigned to the purchaser, as it is in the best position to carry out the function, it knows a transaction is envisioned and the structure of our law enables the purchaser to take well-knownsteps to discover information about the property. The owner should be protected by right of ownership, however, it makes sense to encourage the owner to take reasonable actions that make its interest more secure. Providing mechanisms for owners to so protect themselves is an aspect of registration; the systemic challenge is to provide the incentives to all actors in the market to promote the honesty and reliability of the system.

\section{WHY SHOULD WE EXPECT FRAUD AND SHARP PRACTICE TO APPEAR IN PRACTICE?}

It has long been recognised that fraud is a field of human creativity, and we should expect new forms of fraud and sharp practice to develop in response to changes in the law and institutional environment:

Fraud is infinite, and were a Court of Equity once to lay down rules, how far they would go, and no farther, in extending their relief against it, or to define strictly the species of evidence of it, the jurisdiction would be cramped, and perpetually evaded by new schemes which the fertility of man's invention would contrive. ${ }^{14}$

Legal thought recognises the always provisional and reactive nature of legal attempts to eradicate fraud as 'Fraud is infinite in variety'. ${ }^{15}$

More recently economists have reflected upon the ubiquity and chameleon nature of fraud and sharp practice. ${ }^{16}$ George Akerlof and Robert Shiller have argued that competitive markets produce fraud and sharp practice, or what they term as 'phishing for phools', through normal market mechanisms: 'competitive markets by their very nature spawn deception and trickery, as a result of the same profit motives that give us our prosperity.' ${ }^{17}$ Akerlof and Shiller do not produce any significant new empirical data or theoretical model, but they do argue that the dominant economics paradigm obscures the important issues of how markets generate harm:

We believe it is wrong - as in the textbooks, and the standard mental frame of almost every economist - only to picture the healthy (i.e. efficient) working of markets, with economic pathologies depicted as due only to externalities and income distributions ... because it means

\footnotetext{
13 In this, it resembles to approach taken to undue influence in Barclays Bank plc v O'Brien [1994] 1 AC 180 (HL), CIBC Mortgages plc v Pitt [1994] 1 AC 200 (HL), and Royal Bank of Scotland v Etridge (No 2) [2001] UKHL 44, [2002] 2 AC 77. See Graham Ferris, 'Why is the law of undue influence so hard to understand and apply?' in Elizabeth Cooke (ed) Modern Studies in Property Law (Oxford, Hart Publishing, 2007) 49.

14 Lord Hardwicke as cited in PJ Baker and P St J Langan, Snell's Principles of Equity 28th edn (London, Sweet \& Maxwell, 1982) 538.

${ }^{15}$ Reddaway v Banham [1896] AC 199 (HL), 221.

16 George A Akerlof and Robert J Shiller, Phishing for Phools: The Economics of Manipulation and Deception (Princeton, Princeton University Press, 2015), see book review Graham Ferris (2016) 25 Nottingham Law Journal 162.

${ }^{17}$ Akerlof and Shiller (2015), 165.
} 
that modern economics fails to grapple with deception and trickery. People's naivete and susceptibility to deception have been swept under the rug. ${ }^{18}$

Their argument is that systemic and predictable "phishing" should be seen as a normal product of free markets.

Akerlof and Shiller apply the central concept of economic theory- equilibrium- to phishing. Where people are weak-willed and susceptible to irrational forms of persuasion, or unable to judge their own best interests, or lacking in self-knowledge, then businesses will see a profit opportunity. Unfortunately, people are weak-willed, lacking in self-knowledge, unable to calculate their own best interests, and susceptible to persuasion. Therefore, businesses exploit these profi t opportunities and phish for phools, and are successful businesses as a result. ${ }^{19}$

The narrative in Phishing for Phools places the cause of fraud and sharp practices on those engaging in fraud and sharp practices. The system will generate exploitative equilibria as naturally as it will generate beneficial equilibria. As Akerlof and Shiller emphasise, the beneficial equilibria have brought unparalleled benefits, but that does not negate the detrimental effects of the exploitative equilibria. The characteristics of individual agents, consumers or businesspeople, have little intrinsic role to play in such an equilibrium analysis. However, as Akerlof and Shiller emphasise, our narratives are very important. Economists do have a narrative of cause, and they place their emphasis on the phools, consumers who fail to live up to (or down to) the requirements of economic man. Hence, the emphasis on advice, education, and improving decision-making in regulatory discourse. ${ }^{20}$

What the standard economic accounts and the regulatory responses to identified risk miss is the central point, that the problems are systemic and not individual. Markets naturally produce exploitative equilibria. Thus, both legal and economic thought support an approach to fraud and sharp practice that is responsive and assumes that there is no a priori solution. Human ingenuity seeking to find the highest profits will al ways devise means to exploit the features of any fixed definition or institutional response to fraud and sharp practice. Therefore, the response has to be based in principle rather than in rule, and will be more effective the more it can align the incentives of parties with honest practice.

\section{WHAT INSTITUTIONAL FEATURES PRODUCE COOPERATIVE ACTION?}

Douglass North makes a distinction between the institutional structure of social action, and the organisations that act within and in response to that structure. ${ }^{21}$ The distinction is not one of essence (for some purposes the Land Registry may be institutional and for some purposes it may be an organisation), but the distinction is essential for clarity of analysis.

\footnotetext{
18 Akerl of and Shiller (2015), 164: here "efficiency" means optimal allocation of resources.

19 Akerl of and Shiller (2015), 1-9.

${ }^{20}$ Harry McVea, 'Financial Services Regulation Under the Financial Services Authority: A reassertion of the market failure thesis?' (2005) 64 CV 413; Lorna Fox O'Mahony and Louise Overton, 'Financial Advice, Differentiated Consumers, and the Regulation of Equity-release Transactions' (2014) 41 Journal of Law and Society 446; Office of Fair Trading, Sale and rent back: An OFT market study (OFT1018, 2008) http://oft.gov.uk/OFTwork/publications/publication-categories/reports/consumer-protection/oft1018 accessed 7 October 2015.

${ }^{21}$ Douglass C North, Institutions, Institutional Change and Economic Performance (Cambridge, Cambridge University Press, 1990), 4-5. See also Elinor Ostrom, Understanding institutional Diversity (Princeton, Princeton University Press. 2005), loc 3766.
} 
The level of analysis will often determine whether the Land Registry is to be treated as organisation orinstitution. From the point of view of a lender seeking to ensure recovery of its debts through the use of a mortgage, the Land Registry is an institution. From the point of view of the legislature when framing the powers and duties of the Land Registrar, it is an organisation. ${ }^{22}$ The key to classification is asking, for present purposes of analysis, whether the Land Registry is part of the rules of the game being played or is a player in a game.

Organisations will invest in developing knowledge and understanding and expertise in response to the institutional structure they face. ${ }^{23}$ The market will not naturally distinguish between socially beneficial investment and economic activity, and socially detrimental investment and economic activity. There will be an equilibrium responding to the possibilities of phishing for phools:

The institutional matrix defines the opportunity set, be it one that makes the highest pay-offs in an economy income redistribution or one that provides the highest pay-offs to productive activity. While every economy provides a mixed set of incentives for both types of activity, the relative weights are crucial factors in its performance. The organizations that come into existence will reflect the pay-off structure. More than that, the direction of their investment in skills and knowledge will equallyreflect the underlying incentive structure. If the highest rate of return in an economy is to piracy we can expect that the organizations will invest in skills and knowledge that will make them better pirates. ${ }^{24}$

Thus, if fraud and sharp practice will arise whenever it can produce higher than normal profits, then systems need to be designed to minimise profitable opportunities for such conduct.

We tend to think of the Land Registry as an institution. However, it is important to also think about it as an organisation - and what incentives it has to act in various ways. If it merely seeks to minimise costs it may under-produce public goods. A simple example is the power under paragraph 10(1)(a) of Schedule 8 of the Land Registration Act 2002 to pursue at law the person ultimately responsible for payment of an indemnity through their fraud. Viewed as an asset of the Land Registry, or income opportunity, only easy cases would be pursued, as investigationand litigation are expensive and hazardous. Viewed as a duty to police fraudulent conduct in the land market, through civil sanction, all cases should be investigated with a view to enforcement whenever possible, on a test similar to that used by the Crown Prosecution Service. If this view is taken the power will almost certainly be a drain on Land Registry resources, but promises to deliver a public good.

\footnotetext{
22 In this context the lobby activities of Fortescue-Brickdale can be understood. See: Cornish \& Clark (1989), 176; Anderson in Cornish et al (2010), 202, 219; Avner Offer, Property and Politics 1870-1914: Landownership, Law, Ideology and Urban Development in England (Cambridge, Cambridge University Press, 1981) 71-87. See Elinor Ostrom, Governing the Commons: the evolution of institutions for collective action (Cambridge, Cambridge University Press, 1990), and Ostrom (2005) for levels of analysis.

23 Douglass C North, Understanding the Process of Economic Change (Princeton, Princeton University Press, 2005) 59-64 24 North (2005), 61. See Graham Ferris, 'The Path-dependent Problem of Exporting the Rule of Law' (2012) 101 The Round Table 363.
} 
North tells us what questions needs to be answered, but his analysis is more abstract than the level of analysis at which lawyers work. ${ }^{25}$ We need an approach that can ask more detailed questions that are better suited to our purposes. ${ }^{26}$

Elinor Ostrom studied problems around cooperative action in the context of common pool resources. ${ }^{27}$ As common pool resources share characteristics with public goods, and the provision of an institutional frame that supports land transactions is a public good, some of this research can be directly applied to land law. Also, Ostrom was working towards a set of universally applicable concepts and methods, so we can consider common resources as her starting point rather than the limit of her theoretical ambition. ${ }^{28}$ Ostrom found that a vital feature of successful common pool resource schemes was effective monitoring, sometimes through appointed officials, but al ways with a strong element of mutual monitoring. ${ }^{29}$ Effective monitoring requires both opportunity and motivation. Investigation of title serves the function of tying self-interest to monitoring of other actors in the land market, hence the prophylactic effect of the bona fide purchaser doctrine discussed above. Good institutional design will preserve, so far as possible, this monitoring effect under land registration.

The Land Register makes public information about the land title, thereby facilitating discovery of false claims to title. The Land Registry has robust systemsto avoid the entry of false information on the Register. Guaranteed title limits the need to investigate how an entry was obtained on the Register. This is a vital advantage of registration that lowers transaction costs. There is no need to investigate prior transactions, which is expensive and not optimal, as monitoring should focus on current practice.

Prima facie guarantee of title, subject to possible rectification, which in turn substitutes compensation for title guarantee in appropriate circumstances, is a paradigmatic feature of the English and Welsh system of land registration. The prima facie guarantee suffices for the vast majority of transactions, and is a central element in the efficiency of the system. Rectification, it will be argued below, could be made more comprehensible in practice, but the current legal position reflects broadly a good compromise between efficiency, justice, and the control of fraud and sharp-practice. Provisions that deny legal effect to the registration of forged documentation would strengthen the position of a registered owner, but at the expense of imposing a potentially arbitrary cost upon good faith purchasers. A system of prima facie effective title, subject to possible rectification is in principle a better system, just as the bona fide doctrine was a better response to threats to static security than the nemo dat doctrine, as argued above.

The guarantee of title leaves some room for self-interested monitoring to play a beneficial role. Due to rectification, entries obtained through the use of forged documentation or identity theft can be altered.$^{30}$ Indemnity will not be paid to those who suffer loss from a rectification that was

\footnotetext{
${ }^{25}$ However, see Boniface Chimpango, The Development of African Capital Markets: A Legal and Institutional Approach (unpublished PhD, 2014).

${ }^{26}$ For one attempt to formulate a model for the land market see Gabriel Brennan, The Impact of eConveyancing on Title Registration: A Risk Assessment (Cham, Springer, 2015).

27 Alis on Clarke, 'The Life and Work of Elinor Ostrom' (2014) 22 Nottingham Law Journal 141.

28 Ostrom, (2005). Ostrom referred to this as the Institutional Analysis and Development framework (IAD)

29 Ostrom (1990) Chapter 3,

30 Land Registration Act 2002 Schedule 4.
} 
necessary due to their own fraud or lack of care. ${ }^{31}$ Therefore, a person taking as purchaser has incentives to be on their guard against fraud. ${ }^{32}$

Therefore, many of the features of the current system of land registration are in line with institutional design features identified by Ostrom that are associated with successful long-term collaborative action. ${ }^{33}$ Despite a lack of a clear justice narrative in land registration, there are important elements of land registration that can protect static security rights and counteract fraud and sharp practice, thereby providing materials for constructing a robust narrative about fairness in land registration.

\section{NORTH EAST PROPERTY BUYERS LITIGATION}

There was, in the recent past, a form of phishing known as the sale and rent back market. ${ }^{34}$ People who were desperate to retain occupation of their homes, whose occupation was threatened by debts secured upon the land by mortgages that had fallen into arrears, were offered a life-line by businesses. The businesses offered to purchase their homes, at a significant discount, pay off any secured debts, and rent the property back to the vendor for a guaranteed long period of time. The businesses advertised upon television, and in National newspapers, and had professional looking websites- and were seen by the vendors as legitimate businesses. However, this was a phishing market, and very many of the businesses were telling lies to obtain money which they could keep in exchange for promises they could break.

Central to the phish was the availability of cash, from loans made by lenders who would lend on the security of the acquisition mortgages taken out by the purchasers. In almost all cases, these loans could only be obtained if the purchaser agreed that no longer or more secure tenancy than an assured shorthold tenancy for six months would be granted. Therefore, central to the whole phish was the telling by the phisher of two inconsistent stories to the other two parties: the vendor was promised a secure long term tenancy arrangement, ${ }^{35}$ and the lender was promised the land would only be let on short term insecure tenancies. When the payments under the mortgages were not made by the purchasers the lenders enforced against the property, and sought possession against the vendors. At this point the vendors became aware they had been phished, as they had lost the equ ity in their homes and had not received any security of occupation in return. The courts had to decide which of the two deceived parties, the vendors or the mortgagees, had priority. ${ }^{36}$

\footnotetext{
${ }^{31}$ Land Registration Act 2002 Schedule 8 para 5.

32 Not only fraud of course, but discoverable overriding interests. Schedule 3 paragraph 2 of the LRA 202 is obviously drafted to encourage self-interested monitoring and to protect a purchaser from undiscoverable interests.

33 Obviously some feature she identifies arelimited in application to CPRs and there is insufficient space here to exploreall of the relevant features: Ostrom (1990), table 3.1, 90.

${ }^{34}$ For this and the next two paragraphs see Office of Fair Trading, Sale and Rent Back: An OFT market survey (OFT1018, 2008) and Annex A, B, K and L; the facts set out in Redstone Mortgages plc v Welch [2009] 3 E G L R 71 (CC); and the facts set out in Southern Pacific Mortgages Ltd v Scott [2014] UKSC 52, [2015] AC 385. The sector is now regulated by the FCA but seems to evidence no activity, in a regulated form the market does not function..

35 Sometimes only an assured shorthold for a short term was promised to vendors, but combined with an assurance of subsequent grants, with or without terms limiting rent increases for the subsequent grants. ${ }^{36}$ As noted by Behrens J in Various Mortgagors v Various Mortgagees [2010] EWHC 2991 (Ch), [24].
} 
The law, specifically the equity jurisdiction, has a long tradition of protecting people who are vulnerable to being phished out of their property:

On the other hand, to protect people from being forced, tricked or misled in any way by others into parting with their property is one of the most legitimate objects of all laws; and the equitable doctrine of undue influence has grown out of and been developed by the necessity of grappling with insidious forms of spiritual tyranny and with the infinite varieties of fraud. ${ }^{37}$

In Redstone Mortgages plcv Welch, ${ }^{38}$ an early case dealing with sale and rent back, the court ruled in accordance with this tradition, and held that the vendors were protected, due to the promise s made to them by the purchasers. It was held that these promises, and the detrimental reliance upon them by the vendors, affected the estate in the purchaser's hands, and created an interest that had priority over the mortgages of the lenders. After all, the vendors had been in occupation through the transactions and remained in occupation until the lender sought possession under the mo rtgage. There was an obvious argument that the case concerned an overriding interest. ${ }^{39}$

One obstacle in the path of this conclusion was Abbey National Building Society v Cann.${ }^{40}$ Cann held that acquisition mortgagees had priority over any competing interest that arose upon acquisition of land. The law was derived from cases deal ing with priority upon insolvency, ${ }^{41}$ and gave a principled priority to purchase money interests-security interests that operate upon the very asset the secured credit made it possible for the insolvent entity to acquire. ${ }^{42}$ Cann extended this purchase money security logic to competing interests other than other charges, overruling a line of cases concemed with priority disputes between tenants and mortgagees in the process. ${ }^{43}$ Since Cann, the ratio has been extended in two ways..$^{44}$ It was extended to the contract, so that contract, transfer and mortgage were all treated as a single indivisible transaction in Nationwide Anglia Building Society v Ahmed; ${ }^{45}$ and it was extended to an interest other than an acquisition mortgage in Whale $v$ Viasystems Technograph Ltd. ${ }^{46}$

In Whale the purchase money security principle was applied. The premium for the interest given priority (an underlease) provided the finance to obtain the asset (the headlease). Once the possibility of an interest other than an acquisition mortgage gaining Cann priority existed, the possibility of a clash of purchase money type interests arose in theory. The judge in Redstone in effect

\footnotetext{
${ }^{37}$ Allcard v Skinner (1887) 36 ChD 145 (CA), 183.

38 [2009] 3 EG LR 71 (CC).

39 Under Land Registration Act 2002 Schedule 3 paragraph 2 and developed in Rawden Crozier, 'A question of priorities: mortgages, sell-to-rent-back tenancies and overriding interests' (2012) Landlord \& Tenant Review 220.

40 [1991] 1 AC 56 (HL).

41 In Re Connolly Brothers, Limited (No. 2) [1912] 2 Ch 25 (CA); Security Trust Co. Appellant v Royal Bank of Canada Respondent [1976] AC 503 (PC).

42 Law Com CP164 paras 4.155-4.156.

${ }^{43}$ Church of England Building Society v Piskor [1954] Ch 553 (CA).

${ }^{44}$ In Stroud Architectural Systems Ltd v John Laing Construction Ltd [1994] British Company Law Cases 18 (HC) the ratio of Cann was assumed to apply to goods.

45 Nationwide Anglia Building Society v Ahmed (1995) 70 P\&CR 381 (CA). The point did not have to be decided for the ratio of the Supreme Court in Southern Pacific Mortgages v Scott, Collins and Sumption [85] thought Ahmed was correct and should be extended generally treating the three legal events as indivisible, the majority rejected the extension of Cann to contracts in the normal run of events [121] and [123].

${ }^{46}$ Whale v Viasystems Technograph Ltd [2002] EWCA Civ 480.
} 
analysed the sale and rent back transaction as a clash of two purchase money interests: the vendor's interest and the interest of the acquisition mortgagee. ${ }^{47}$

Redstone threatened the interests of acquisition mortgagees in sale and rent back cases, and the number of these cases starting to appear in the courts on possession hearings was increasing. A test case was litigated, involving numerous vendors and mortgagees to nomineesfor an entity known as North East Property Buyers. ${ }^{48}$

Thus, the North East Property Buyers litigation provides a clear example of phishing, fraud or sharp practice in the market. The technical resolution of the dispute was made through an analysis of the interest held by a purchaser under the contract to buy land. Due to specific performance the purchaser obtains an equitable property interest of some type. ${ }^{49}$ The Supreme Court held that this interest was not sufficient to support a grant to another of an equitable interest in the legal estate. ${ }^{50}$ Therefore, there was no proprietary interest capable of being made overriding by occupation of the vendor upon completion under paragraph 2 of Schedule 3 of the Land Registration Act 2002. Therefore, the vendors had to give up possession to the mortgagees.

Both Lord Collins and Baroness Hale expressed sympathy with the vendor, Mrs Scott, and other vendors who faced repossession after selling to nominees of North East Property Buyers. ${ }^{51}$ Nevertheless, the law and, for Lord Collins at least, the policy behind the law, meant that the mortgagees must prevail. ${ }^{52}$ However, neither substantive judgment argued that this was so because it advanced the principled aims of the registration system. The defence of registration was made in terms of efficiency through low transaction cost and certainty. Etherton $\sqcup$ in the Court of Appeal had tried to defend the law in terms of principles, but ended up blaming the vendor victims in the process. ${ }^{53}$

Not only was no narrative of the principles behind registration given in justice terms, it was asserted implicitly by Baroness Hale that registration has no such justificatory pri nci ples, claiming that: 'It is important to bear in mind that the system of land registration is merely conveyancing machinery'. ${ }^{54}$ She proceeded to identify three potentially conflicting and potentially aligned 'policies' at play, namely (i) the importance of protecting dynamic security, (ii) the protection of overriding interests without registration, and (iii) the accuracy of the Register (by which she seems to have intended its correspondence to the legal position prior to registration ). ${ }^{55}$ Baroness Hale described the first and third of these as 'public policies'.

Thus, Southern Pacific Mortgages v Scott, as the North East Property Buyers litigation was known in the Supreme Court, with its emphasis on public policy, provides strong evidence of a lack of a justice narrative in connection with registration. It also provides evidence of a judicial reluctance to abandon the victims of fraud and sharp practice to the mechanics of the conveyancing machinery:

\footnotetext{
47 [1994] BCC 18 (HC) [63].

48 Various Mortgagors v Various Mortgagees [2010] EWHC 2991 (Ch); Mortgage Business plc v O'Shaughnessy [2012] EWCA Civ 17, [2012] 1 WLR 1521; Southern Pacific Mortgages v Scott [2014] UKSC 52, [2015] AC 385.

49 Raynorv Preston (1881) 18 Ch D 1 (CA).

50 [2014] UKSC 52, [2015] AC 385 [60] - [79] per Lord Collins, and [104] - [112] per Baroness Hale.

51 [2014] UKSC 52, [2015] AC 385 [24] and [94] per Lord Collins, and [95] and [122] per Baroness Hale.

52 [2014] UKSC 52, [2015] AC 385 [25] and [35] - [37] per Lord Collins, [97] and [122] per Baroness Hale.

53 Mortgage Business plc v O'Shaughnessy [2012] EWCA Civ 17, [2012] 1 WLR 1521, [55] - [56].

54 [2014] UKSC 52, [2015] AC 385 [96].

55 [2014] UKSC 52, [2015] AC 385 [97].
} 
I confess to some uneasiness ... Should there not come a point when a vendor who has been tricked out of her property can assert her rights even against a subsequent purchaser or mortgagee? ... Should there not come a point when the claims of lenders who failed to heed the obvious warning signs that would have told them that this borrower was not a good risk are postponed to those of vendors who have been made promises that the borrowers cannot keep? ${ }^{56}$

In this passage, the arguments seem to be directed to issues of fairness rather than efficiency. However, it Baroness Hale's Judgment offers no solutions for the problems felt to lie in a technocratic system which is unable to moderate its response to fraud or sharp practice in order to fulfil 'one of the most legitimate objects of all laws' by protecting the victims of trickery, cajolery or bullying. ${ }^{57}$

\section{MACLEOD v GOLD HARP PROPERTIES LTD}

Priorities and fraud or sharp practice came up again in the case of MacLeod $v$ Gold Harp Properties $L t d{ }^{58}$ Once again a businessman, one $\mathrm{Mr}$ Ralph $\mathrm{Snr}$ sought to phish for phools and acquire valuable property, without having to reach an agreement with the owners nor pay them a market price:

On the judge's findings - which indeed reflect his [Mr Ralph Snr] own candid admissions in evidence -he orchestrated a sequence of events which he hoped would enable him to acquire the roof space without having to make any payment to the claimants. The judge found that $\mathrm{Mr}$ Ralph was aware that 'the claimants ... and their agents were some what unworldlyfolk, not well attuned to defeating attempts to take their property'. ${ }^{59}$

The property desired was the third floor of a house in London, and subject to two long leases which divided the floor into two halves. ${ }^{60}$ The tenants spent a lot of time in Africa, and relied upon their local agents and attorneys, Mr Gibbons and Mr MacLeod, to manage their interestsin the UK. The landlord, Mr Ralph Snr, was a property developer who had previously acquired both the freehold and the leasehold interests in the ground and first floors of the property. He planned to forfeit the leases for non-payment of ground rent, and then to grant a new lease to a nominee, who would pass it on to another nominee, who would pass it on to Gold Harp- a company owned and controlled by Mr Ralph Snr. The first stage was to transfer the freehold to Mr Ralph Jnr, who became entitled to the ground rent and whose address was unknown to the leaseholders; it was found by the judge that Mr Ralph Jnr would act upon the direction of Mr Ralph Snr.

Ground rent was not paid on time, and bailiffs were instructed to make a formal re-entry. However, this move was premature. The ground rent was delivered to the address of Mr Ralph Snr before the leases became liable to forfeiture, but not accepted in payment or passed on to Mr Ralph Jnr. The judge found this tender to be effective, therefore there had been no forfeiture of the leases.

Mr Ralph Jnr made a statutory declaration declaring re-entry by bailiffs on a date that would have justified forfeiture for non-payment of ground rent. Three days later he sent the declaration, and a letter in support, to the Land Registry together with an application to close the two leasehold titles. The Land Registry accepted these documents as valid. Therefore, the Registry closed the substantive

\footnotetext{
56 [2014] UKSC 52, [2015] AC 385 [122] per Hale.

57 Allcard v Skinner (1887) 36 ChD145 (CA), 183.

58 MacLeod v Gold Harp Properties Ltd [2014] EWCA Civ, [2015] 1 WLR 1249.

59 [2014] EWCA Civ, [2015] 1 WLR 1249, [5].

60 This paragraph and the next three are a summary of [2014] EWCA Civ, [2015] 1 WLR 1249, [1] - [12].
} 
title entries for the leasehold titles, and removed the notice of the lea ses from the freehold title. As a result, the Register showed a third floor unencumbered by any leases at this point. Mr Ralph Jnr then granted a long lease to a nominee of Mr Ralph Snr, which nominee assigned to a second nominee, which assigned to Gold Harp. Although the original grant and each assignment recorded purchase monies the judge found no money changed hands. The grant and subsequent assignments were recorded on the Register, a new substantive title for the long lease granted was created, and the lease was noted on the freehold title.

The judge found that Mr Ralph Snr was guilty of sharp practice but not fraud. However, the closures of the titles of the tenants were mistakes, as was the removal of the entries on the leases schedule to the freehold. There had been no forfeiture. Therefore, he ordered the Register to be rectified, under the powers given to the court by Schedule 4 of the Land Registration Act 2002. ${ }^{61}$ This raised the issue of the priority between the restored leases and the newly granted lease. At the time of the grant there had been no adverse entry, so if the purchaser could rely upon the Register then the new lease should be given priority. However, if the new lease was given priority over the older leases then the act of rectification was futile, as the new lease would effectively retain all the value. The judge ordered that the restored leases should be given priority over the new lease, in effect rendering the new lease valueless. ${ }^{62}$

Both the judge and the Court of Appeal ignored the impact of the finding that no valuable consideration had been paid for the new lease upon grant or upon assignment. Therefore, section 29 of the Land Registration Act 2002 did not apply, and it was section 28 that governed priorities. ${ }^{63}$ The point was noticed late and not argued, and the case was resolved through the interpretation of paragraph 8 of schedule 4 of the Land Registration Act 2002 which reads:

Rectification and Derivative Interests

The powers under this schedule to alter the register, so far as relating to rectification, extend to changing for the future the priority of any interest affecting the registered estate or charge concerned.

The argument revolved around what was intended by 'changing for the future the priority'.

If the words prohibited affecting priority obtained prior to rectification, then the new lease would keep its priority obtained at a date when the old leases were not protected by any entry on the Register. 'For the future' would mean nothing of value was gain ed through rectification, merely that subsequent encumbrances would take subject to the old leases. This construction would uphold the interests of anyone who relied upon the Register - even a person who deliberately engineered the situation in order to rely upon the Register through sharp practice. ${ }^{64}$ In Gold Harp the Court of Appeal, in line with legal developments in the decisions of the deputy adjudicators of the Land Registry,

\footnotetext{
61 [2014] EWCA Civ 1084, [2015] 1 WLR 1249, [26].

62 The problem is closely a nalogous to one analysed in Amy Goymour, 'Mistaken registrations of land: exploding the myth of "title by registration"' (2013) 72 CV 617. See also [2015] Conv 253.

63 [2014] EWCA Civ 1084, [2015] 1 WLR 1249, [10], [15], [18], and [34].

64 Compare Midland Bank Trust Co Ltd v Green [1981] AC $513(\mathrm{HL})$.
} 
construed the words narrowly, ${ }^{65}$ and upheld the judge' sorder that gave priority to the old leases over the new lease.

Gold Harp thus extended the ratio of the earlier case law, and in order to do so imposed a somewhat strained interpretation of the statutory words. To make the alteration of the Register effective it was necessary to have the power to alter priorities between derivative interests - the old leases and the new lease. ${ }^{66}$ The words 'for the future' were read as merely preventing the retrospective arising of any cause of action from actionstaken by the derivative interest h older during the period of time the Register was incorrect. ${ }^{67}$

Underhill $\sqcup$ justified the substance of the decision in three points. First, consistency of treatment within the registration scheme: that priority between derivative interests that arise upon alteration of the register should be treated in the same way as priority issues are resolved when an owner of a registered title and a derivative interest holder are in conflict, as in Argyle Building Society $v$ Hammond. ${ }^{68}$ Second, that registered title is not absolutely indefeasible as rectification is possible. Third, that Schedule 4 al lows a fair balance between competing interests to be struck, and the right to an indemnity can compensate an interest holder who loses. ${ }^{69}$

As Goymour notes this account of the reasons behind the law is lacking. As argued above registration requires a principled narrative:

From a presentational perspective, it is schizophrenic and misleading for the LRA 2002 to make promises of title security and priority in the main body of the Act, but for those promises to be nullified via its alteration provisions (as expansively interpreted by the courts), which are sparse on detail and less visibly positioned within the Acts Schedules. ${ }^{70}$

However, the difficulty is less in the drafting of the Act than the failure to articulate the disparate aims of the system. The law rightly safeguards static security as well as dynamic security, and the judiciary is rightly unwilling to allow practitioners of sharp practice and fraud to exploit title security that is provided as a public good to those involved in the land market.

Both Goymour and Baroness Hale present this tension as one between general propertylaw and registration. ${ }^{71}$ In the context of alteration and rectification of the Register it might be argued that judicial developments mean that it is the general law that is dominant. But as Goymour suggests we will be better served by an integration of two aspects of one system..$^{72}$ However, this cannot be done whilst registration rhetoric adheres to an exclusive focus on dynamic security justified by appeals to efficiency. Judges are unwilling to permit phishers and fraudsters to prevail, and this judicial instinct is correct. In short lack of an articulated justice principle in justifications of re gistration combined with judicial hostility to fraud and sharp practice are putting pressure on such concepts as statutory title. The pressure on statutory title and the reliability of the Register suggests that an exclusive focus upon

\footnotetext{
65 Ajibade v Bank of Scotland plc (Ref 2006/0163/0174), Stewart v Lancashire Mortgage Corpn Ltd (Ref 2009/86), Knights Construction (March) Ltd v Roberto Mac Ltd [2011] 2 EGLR 123.

66 [2014] EWCA Civ 1084, [2015] 1 WLR 1249, [92]-[96].

67[2014] EWCA Civ 1084, [2015] 1 WLR 1249, [96].

${ }^{68}$ [2014] EWCA Civ 1084, [2015] 1 WLR 1249, [97]; Argyle Building Society v Hammond (1985) 49 P \& CR 148

(CA).

69 Although presumably not in Gold Harp.

70 [2015] Conv 253, 265.

71 (2013) 72 CL 617,649-650; [2015] Conv 253, 265-266; [2014] UKSC 52, [2015] AC 385 [96]

72 (2013) 72 CL 617, 650.
} 
efficiency is not only inadequate as a narrative but is also untenable. The demands of static security and the justice of protecting people from fraud and sharp practice are proving too strong.

There is no inherent reason why registration should pretend it can ignore the ethical quality of the users of the registration system, and such a posture has not been adopted universally: ${ }^{73}$

As far as the powers of rectification are concerned... rectification should be available whenever the register does not accurately reflect the title to the land according to the otherwise established rules of land law ... and rectification would be just in all the circumstance (in particular if it is shown that there has been fraud in the obtaining of an entry in the register, or if the transferee or grantee lacked good faith or did not give value).

Property law has to deal with situations in which both parties may be innocent of any wrong. Registration seems to offer a technocratic neutral arbiter between the innocent, but, because it imposes priority without taking into account circumstances and conduct, only at the cost of being an arbitrary arbiter. Therefore, there is need to recognise a central role for rectification. As Simon Cooper argues: 'The inability of the vesting rule to distinguish the meritorious from unmeritorious indicates the desirability of a liberal regime for correction which possesses the sophistication to undertake a more sensitive assessment of competing priority claims' ${ }^{74}$ Where there is misconduct then protection of victims, and pursuit of malefactors are ends that justify higher transaction costs if necessary.

\section{SWIFT $1^{\text {ST }}$ LTD v THE CHIEF LAND REGISTRAR}

Swift $1^{\text {st }} L t d v$ The Chief Land Registrar concerned the aftermath of fraudulent charges registered over property belonging to Mrs Rani, who was registered proprietor in occupation throughout the relevant events. ${ }^{75}$

The fraudsters obtained personal information about and personal documents of Mrs Rani, and applied through a broker for a mortgage. Then using the same means did the same again with Swift, a second lender, who redeemed the first mortgage. This phish earned some $f 60,000$. Although the report does not give details of the methods used on the first occasion, we can assume they were similar on both occasions. The fraudsters almost certainly knew what would be required from them by the lender, and prepared accordingly. No one visited the property, and no one met with Mrs Rani, which greatly simplified the fraud.

Several telephone numbers were provided, one of which was a landline, but not to the property. Swift telephoned the landline number. The telephone was answered by a young woman (apparently, over the telephone, younger than Mrs Rani) who had the required personal details, and knowledge of the transaction to pass the standard interrogation. A copy of a debit card with a signature had been provided, but the signature on the card bore no resemblance to the one on the mortgage deed. She was not asked about the discrepancy in the signatures, presumably as it did not form part of the standard script. Neither the lender not the mortgage broker employed a conveyancer,

\footnotetext{
73 Law Commission, Third Report on Land Registration (Law Com No 158, 1987), para 3.6.

${ }^{74}$ Simon Cooper, 'Regulating fallibility in registered land titles' (2013) CL 341, 367.

75 Swift 1st Ltd $v$ The Chief Land Registrar [2015] EWCA Civ 330. The facts summarised in the following two paragraphs are taken from the report of the firstinstance judgment, [2014] EWHC 4866 (Ch), [45]-[63].
} 
presumably to save the cost. The judge held that the precautions taken by Swift met the industry standard at the time of the fraud, and that those standard were not careless. ${ }^{76}$

Swift accepted that there had been a fraud and their charge was based on a forged document, and therefore the Register should be rectified by the removal of the charge. Therefore, they sought an indemnity for their loss, under Schedule 8 of the Land Registration Act 2002, and the Land Registrar opposed them. The Registry argued that Swift had suffered no loss when their charge had been removed from the Register. This was on the basis that Mrs Rani always had an overriding interest in the property free of the charge, or an overriding interest to rectification. Therefore, following Re Chowood's Registered Land, ${ }^{77}$ the al teration of the Register did not change the situation, as Swift never had a valid claim under the charge. ${ }^{78}$ As both parties accepted this logic, that Mrs Rani did have an overriding interest through her occupation and right to rectification,$^{79}$ the case turned upon the construction of paragraph 1 of Schedule 8, in particular paragraph 1(2)(b) which reads:

The proprietor of a registered charge claiming in good faith under a forged disposition is, where the register is rectified, to be regarded as having suffered loss by reason of such rectification as if the disposition had not been forged.

The point of construction was tortuous, and involved the Court of Appeal wrestling with the difference between alteration and rectification, and when the Re Chowood principle should apply; ${ }^{80}$ whether loss and prejudice are synonyms or overlapping terms; the statutory intention behind the provision, and specifically whether it was exclusively directed at reversing the effects of $A-G v$ Odell; $;{ }^{81}$ and whether the decision that a person taking under a forged disposition took only a bare legal title upon registration of the disposition in Malory Enterprises Ltd $v$ Cheshire Homes (UK) Ltd was perincuriam. ${ }^{82}$ Eventually paragraph 1(2)(b) was given a reading that entitled Swift to an indemnity by deeming it had suffered a loss by reason of the rectification.

If the courts are willing to overturn guarantees of statutory title or priority to counteract the effects of fraud, then it is important that indemnity be available to compensate for the consequences of such alterations of the register. ${ }^{83}$ Therefore, Swift is to be welcomed in principle, although resting

\footnotetext{
76 [2014] EWHC 4866 (Ch), [55] and [61].

77 [1933] 1 Ch 574 (Ch).

78 [2015] EWCA Civ 330 [20].

79 [2015] EWCA Civ 330, [37]. However, if the right to rectification founds the overriding interest then it seems to arrive too late to be effective, there is nothing to rectify until the charge is entered on the register, see: Martin Dixon, 'A not so conclusive title register? (2013) 129 LQR 320, 323; Emma Lees, 'Richall Holdings v Fitzwilliam: Malory v Cheshire Homes and the LRA 2002' (2013) 76 MLR 924, 932; Elizabeth Cooke, 'Chickens come home to roost' [2014] 78 Conv 444, 447 n21; Emma Lees, 'Indemnity and the Land Registration Act 2002' (2014) 73 CV 250, 252; Patrick Milne, 'Guarantee of title and void dispositions: work in progress' [2015] 79 Conv 356, 362-363.

80 [1933] 1 Ch 574 (Ch), if the principleapplied before it was determined whether rectification had taken place, which requires the alteration to affect a registered proprietor's title prejudicially, it might mean there was no prejudice and therefore no rectification, merely an alteration, and therefore no right to indemnity could arise, see Schedule 4 paragraph 1(b) and Schedule 8 paragraphs 11(2) and 1(1)(a) Land Registration Act 2002.

${ }^{81}$ A-G v Odell [1906] 2 Ch 47 (CA).

82 Malory Enterprises Ltd v Cheshire Homes (UK) Ltd [2002] EWCA Civ 151, [2002] Ch 216.

83 Martin Dixon, 'Land Registration and Time Travel' (2014) Conv 189, 191; Martin Dixon, 'Rectification and priority: further skirmishes in the land registration war' (2013) CL 207, 213; Emma Lees, 'Indemnity and the Land Registration Act 2002' (2014) 73 CL 250, 253.
} 
the decision on the deeming provisions of paragraph 1(2)(b) leaves other potential casualties of rectification vulnerable. ${ }^{84} \mathrm{It}$ would be preferable for a broader and less arbitrary rule to be established.

However, the approach to industry standards, and the acceptable standards of inquiry by lenders, falls short of what is systemically desirable for monitoring by lenders of other participants in the land market. An industry standard, given the existence of phishing industries as a natural feature of markets, must be subject to critical scrutiny. If an industry de cides to enjoy lower operating costs by not employing conveyancers, thereby accepting increased risk of fraud, then that industry should bear the costs of the fraud it risked. If the Land Registry fee is an insurance premium then it is universal, compulsory, and not adjusted for risk profile. ${ }^{85}$ Therefore, it is susceptible to free-rider problems.

As has been argued above, the land market depends upon self-protective monitoring by participants in the market. Lenders, as organisations, will invest strategical ly. If monitoring, or as we usually term it investigation of title, is thought to be necessary, then they will invest in people and systems to reduce fraud. If all lenders are investing in such activity then there is no competitive disadvantage incurred. If some lenders reduce their antifraud efforts, and rely upon a compulsory insurance system instead, they gain a competitive advantage by free-riding. As more lenders realise the competitive advantage of free-riding the burden on those not free-riding rises, and the pressure to free-ride increases. A phishing equilibrium will be reached, and the public good of an honest land market will be undersupplied. Which returns us to the concerns expressed by Baroness Hale: 'Should there not come a point when the claims of lenders who have failed to heed the obvious warning signs that would have told them that this borrower was not a good risk are postponed'. ${ }^{86}$ Swift represents a damaged compromise. The court should have and did find rectification and loss that justified indemnity. However, the approach taken to care may have been overly influenced by assumptions that industry standards reflect some public interest, because markets naturally incline towards efficiency. This neglects the need to actively maintain honest markets and dangers posed by the phishing equilibrium.

\section{CONCLUSIONS}

Land registration cannot be reduced to the single objective of reduction of transaction costs at the cost of static security and principles of justice. The system has a fundamental interest in the protection of static security, and the judiciary has a strong impulse towards opposing egregious misconduct. The problems the case law is grappling with are generated by the presence of fraud and sharp practice, and these activities are never going to go away because markets produce phishing equilibria as effectively as they produce social benefits. Our institutional design, the law including the law of land registration, the Land Registry, professional conveyancers, the Tribunal and Court system, are the

\footnotetext{
84 Patrick Milne, 'Guarantee of title and void dispositions: work in progress' [2015] Conv 356, 364; Elizabeth Cooke, 'Chickens come home to roost' [2014] 78 Conv 444, 447.

${ }^{85}$ As forcefully put by Lees '... confidence in the register is ... the entire point of the new registration system. By paying your fee, and placing your faith in the Land Registry, they pay when you lose out ... The Land Registry fee can be considered, in effect, an insurance premium' Emma Lees, 'Indemnity and the Land Registration Act 2002' (2014) CL 250, 253.

86 [2014] UKSC 52, [2015] AC 385, [122].
} 
foundations of our land market and all elements need to be responsive to threats from phishing to good faith participants in the market

The cases reviewed demonstrate that there is a tension within our system. Land registration is seen as unprincipled and technocratic. It is not obvious how it embodies principles of protection for static security and institutional guards against fraud and sharp practice. The lack of a principled narrative for registered land is productive of hard cases, as solutions for injustice are sought outside the land registration scheme. ${ }^{87}$

At the same time at a deeper level of analysis we neglect real systemic problems. Partly because our law is mediated through very complex and somewhat opaque statutory provisions. Partly as a residual effect of rhetorical attacks on unregistered conveyancing. Those attacks led to the establishment of a system of land registration that is almost certainly better than the old system. However, they also obscured the systemic importance of the doctrine of the bona fide purchaser: by harnessing self-interest to monitoring and organisational investment in fraud prevention, it helped maintain a public good, an honest land market.

A narrative is a way to understand something. It provides a frame for interpretation and action. In property law both a positive and a negative principle are needed. Land registration lacks a convincing narrative, and to remedy this inadequacy we should start by declaring a principle that land registration exists to protect the interests of good faith purchasers for valuable consideration, and invite the courts to give substantive content to good faith and valuable consideration. Articulation of this positive principle might also help to draw attention to features of land registration that already serve this end. This narrative is not merely rhetorical, but offers a means to develop the law in a principled manner. This is our positive principle.

We should declare that fraud and sharp practice will be met by disfavour, that the law is biased against dishonestly and oppression. Therefore, attempts to use the system for dishonest or oppressive purposes will be opposed and sanctioned. At first the content of dishonesty and oppression will be informed by our existing law, forgery is dishonest, but so are knowing misrepresentations; duress and undue influence of protected categories of people are oppressive, but sometimes the very terms of an agreement may be so one-sided they should lead to protection being extended to people who would not normally be protected. ${ }^{88}$ In time, specific mischiefs in the land market may lead to novel legal response, as fraud is protean a power of novel response is necessary. As part of the enactment of our negative principle, the Land Registry should be subjected to a duty to pursue fraudsters whose schemes lead to rectification and indemnity, not merely to recover money paid out, but as part of the sanctioning system.

The incentive of lenders to rigorously seek out fraud and sharp practice should be reviewed with an eye to the need the land market has for lenders to be vigilant. Title guarantee and indemnity are good principles for land registration. There is sense in awarding purchase money lenders a higher priority than other lenders, including those whose interests and security may pre-date that of the purchase money lender. Overreaching is a necessary mediator between specific property and property as wealth. However, we may have neglected to consider the cumulative effects of all of these

\footnotetext{
87 As exemplified by Malory Enterprises Ltd v Cheshire Homes (UK) Ltd [2002] EWCA Civ 151, [2002] Ch 216.

88 See, eg Credit Lyonnais Bank Nederland v Birch [1997] 1 All ER 144 (CA).
} 
individually defensible legal protections. If lenders are overly secure from the hazards of fraud, then they will be unwilling to bear the necessary costs of maintaining an honest land market. 